\title{
An Evolving Triadic World: A Theoretical Framework for Global Communication Research*
}

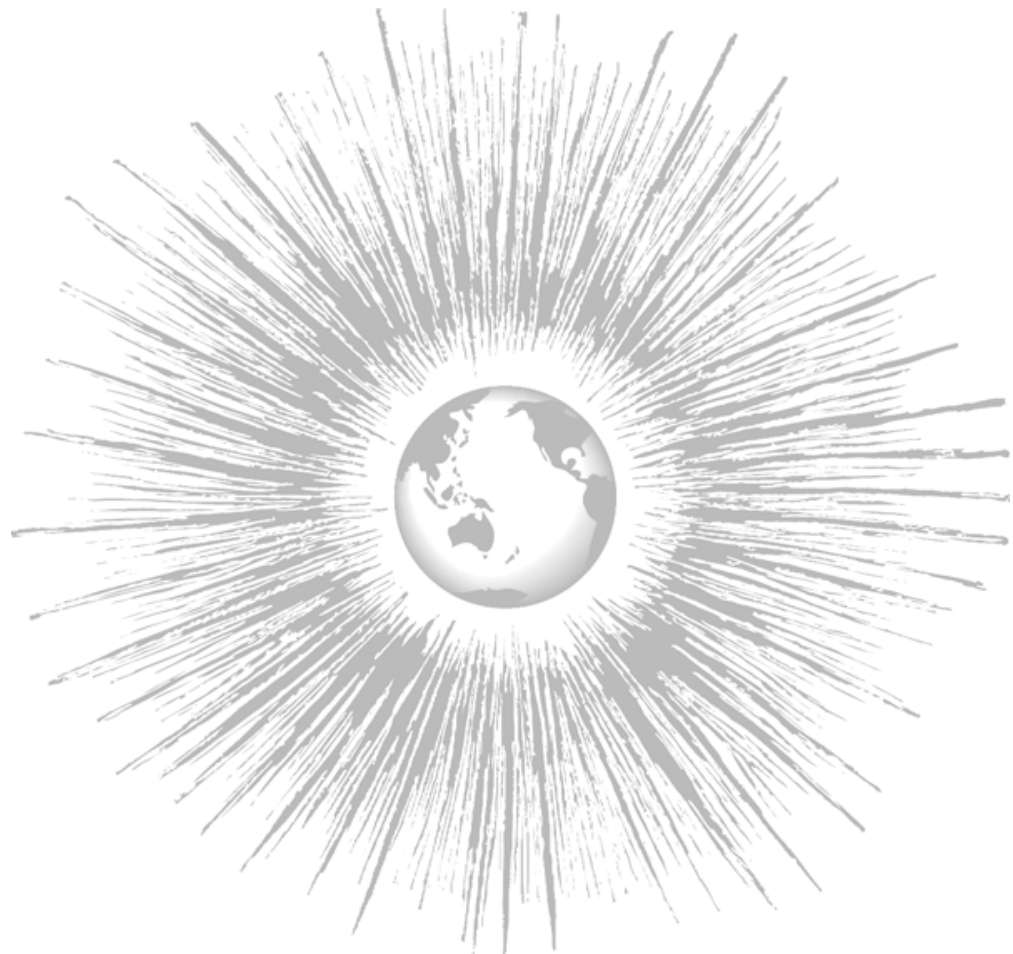

ABSTRACT

A macro theory that recognizes the competing center economic clusters, each of world's three competing center-clusters and which has a dependent binterland comprising their respective hinterlands offers a realistic peripheral economic clusters. These clusters framework for global communication research. may not necessarily be geographically conThis study has used recent data on world tiguous. Strong-weak relationships may exist trade, computers, Internet hosts, and high- within each center-cluster, as well as within tech exports to map the triadization of the each periphery-cluster, with one center-cluster world in the Information Age. The original occupying a hegemonic role. The rudimentary dependency theory and world-system theory Information-Society Power Index, constructed perspectives emphasized the hierarchical link- for this study, can guide the researcher to test ing of national societies to the capitalist world- an abundance of hypotheses on the pattern of economy in a center-periphery structure. The global communication and information flow proposed global-triadization formulation looks with particular attention to source, message, at the center-periphery structure in terms of a channel, and receiver. capitalist world-economy dominated by three
Shelton A. Gunaratne

The recognition of the process of globalization has drawn attention to the shortcomings of the theories that scholars have so far used to study global communication - a concept that is distinct from but often confused with international communication. The "developmentalism" notion of the Parsonsian structural-functionalist modernization paradigm, which presumed that nationstates changed in parallel lines from tradition to modernity, influenced the work of many inter-national communication researchers until the mid-I97os. Researchers also have paid attention to other communication phenomena associated with globalization - transborder data flows, cultural imperialism, media events, global network organizations, etc.- though many of those studies have generally failed to take a global perspective. Changes in the global power structure, attributable primarily to the ongoing globalization process fanned by the Digital Revolution, require us to reformulate and refine relevant aspects of these approaches.

The purpose of this essay is to develop a theoretical framework for global communication research based on a reformulation of the world-systems perspective. Gunaratne (200Ia) has broadly explained the potential for testing global-communication hypotheses within the five components of Frank's inter-

\section{Shelton A. Gunaratne}

Mass Communications Department

Minnesota State University Moorhead

Moorhead, MN 56563

gunarat@mnstate.edu

http://www.mnstate.edu/gunarat/

* This is a revised version of a paper the author presented to the 200 annual convention of the Association for Education in Journalism and Mass Communication in Washington, DC. The author is grateful to Kurt Kent (Florida), Carol Lomicky (Nebraska-Kearney), Mark Hansel, Ariyaratne Wijetunge (both of MSU Moorhead), and the several anonymous reviewers for their advice on the draft of this essay.

JOURNAL OF WORLD-SYSTEMS RESEARCH, VIII, III, FALL 2002, 330-365 bttp://jwsr.ucr.edu

ISSN I076-156x

(C) 2002 Shelton A. Gunaratne 
pretation of the world system ${ }^{1}$ (Frank \& Gills 1993): the world system itself; the process of capital accumulation as the motor force of (world system) history; the core-periphery structure in and of the world system; the alternation between hegemony and rivalry; and the long and short economic cycles of alternating ascending phases and descending phases. Several excellent overviews of the literature spawned by the world-systems perspective already exist (e.g., Shannon 1989; Chase-Dunn \& Grimes 1995; Sanderson \& Hall 1995).

The current study is an attempt to ascertain the suitability of grafting the putative global triadization concept to the world-system theory to try out hitherto untried ways of conducting comparative communication research. The triadization concept itself is not new. What is new is the approach to analyzing each triadized cluster as a single economic unit (rather than as separate political units or nation-states comprising that cluster) for center-cluster comparisons. This approach enables the researcher to include smaller political units (e.g., Belgium) and even low-end developed countries (e.g., Portugal) as part of the center thereby making the controversial semiperiphery concept of the original worldsystem theory virtually redundant. This study has also introduced a new variable, the Information Society Power Index, for comparing nation-states within each economic cluster, as well as the triadized center-clusters, and placing them in the appropriate center-periphery structure. Based on the literature review, this study focused on two main research propositions:

I. The pattern of world exports supports the existence of three world center clusters each of which has at least one dependent periphery cluster. (Old controversial hypothesis)

2. The distribution of computing power and exports of high-technology manufactures (constituting the Information Society Power Index) will confirm the triadization structure and help identify the hegemon cluster of the triad. (New hypothesis)

1. Differences exist between Wallerstein's world-systems (plural and hyphenated) perspective and Frank's world system (singular and unhyphenated) perspective. Frank (2000) points out that his formulation is humanocentric and global whereas Wallerstein's is highly Eurocentric. Wallerstein (1979) has traced two world-systems up to now: worldempires (unified political systems that have existed since the Neolithic Revolution, e.g., Byzantium, China, Egypt, Rome, feudal Europe, feudal Japan), and world-economies (marked by a single division of labor but no overarching political structure). Wallerstein says that the $16^{\text {th }}$ century marked the beginning of the modern world-system centered on Europe; and what distinguished it from previous world-systems was ceaseless capital accumulation. This essay retains world-systems, as well as world system, to express distinct intents.
The findings of this study clearly confirmed both propositions. These findings provide a new theoretical framework for global (holistic) or international (partly holistic) communication researchers to embark on projects to ascertain the inter-and intra-communication patterns/processes of the world's three competing center-clusters: the center-periphery communication patterns/processes related to each of the these center-clusters, the inter-and intra-communication patterns/processes of the periphery clusters, and the significance of the hegemon cluster vis-à-vis all other macro and micro units in the world system. The particular contribution of this approach is the potential it offers to examine global or international communication patterns/processes (source-message-medium-receiver-effect) bolistically by recognizing the part-whole interrelationships of all theoretical components of the world system. Thus, the hermeneutics of communication research findings would have to entail the five dimensions of the world system mentioned in the second paragraph. This study also fits rather well with the continuing tradition of concern with cultural ties (e.g., Galtung 197I) or the network blocks of cultural ties ("blockmodel" analysis) of the world system (e.g., Kick 1987).

The next section of this essay will focus primarily on the more recent literature on the subject and demonstrate how I derived this study's theoretical framework. The third section will elaborate on the concepts and methods I used in the study. The fourth section will elaborate on the findings. The final section will provide a discussion of the related issues.

\section{LITERATURE REVIEW}

The structure of the basic argument of the world-systems perspective, according to Goldfrank (2000:178), is that capitalism is a world-economy comprising "core, peripheral, and semi-peripheral productive regions integrated by market mechanisms which are in turn distorted by the stronger of the competing states, none of which is strong enough to control the entire economy." Wallerstein's (1974) formulation of this perspective borrowed the core-periphery concept from the dependency theory (see Gunaratne \& Conteh 1988) and added the concept of the semi-periphery. The world-systems theory sees the world "as developed and underdeveloped states, or zones, the interaction of which, through unequal exchange processes, produces a global core-periphery division of labor" (Bergesen 1990:67). It uses totalities as units of analysis to describe social change. It postulates the capitalist world-economy as the basic unit of analysis. Trade and exchange constitute the primary social mechanism that integrates the global system. Bergesen criticizes the world-system theory, as well as the internationalrelations theory in political science, because "both begin with the individualist assumption that we begin with an aggregate of states and then move toward 
international order, rather than the collectivist assumption that we begin with an international order and only then derive the presence of states and national economies" (p. 68). Bergesen says that the world-systems approach should "place culture and power at the heart of the analysis and replace the individualism implied in the idea of a division of labor, unequal or not" (p. 80). Bergesen's suggestion confirms the need for global-communication research to emphasize the global framework rather than the atomistic nation states.

Unlike the structural-functionalist modernization paradigm, which occupied the center-stage of social science inquiry until the mid-I970s, the new worldsystem paradigm helped explain not only the historic North-South inequality but also the rise of the newly industrialized countries. It shifted attention from the nation-state to the world-system as the relevant unit of analysis. However, Schramm and Lerner (1976), two of the pre-eminent communication scholars at the time, failed to assess the significance of the world-system perspective's epistemological and hermeneutical challenge when they edited their book on rethinking communication and change. Many contemporary developmental-communication scholars (e.g. Shah 1996) also continue to exclude the world system perspective, while a few (e.g. Servaes 1999) have attempted to incorporate it. In general, this perspective has not yet received adequate attention in most discussions on communication theory as a field.

McMichael (2000:669) points out that the world-systems perspective saw development as a systemic process, "where core-periphery relations were the real development dynamic and core states were outcomes, rather than units, of development." McMichael contends that the accelerated compression of time and space in the current era of "financialization" has helped transform nation states into global states, a phenomenon synonymous with the decomposition of wage-labor as a social institution. This interpretation provides a challenge to researchers engaged in the study of communication and development, as well as the global flow of information. Teivainen (2000) argues that to face the politi$\mathrm{cal}$ and theoretical challenges of the futures of the world system, scholars must redraw the modernist map of political space (i.e., the territorialist and singleperspectival conception of social space) used by the traditional world-systems approach.

Sklair (1999) asserts that the process of globalization has made it difficult to study many contemporary problems at the level of nation states, that is, in terms of each country and its inter-national relations. Instead, researchers need to conceptualize such problems in terms of global processes. However, Sklair points out the clear need to establish a distinction between the inter-national and the global. He categorizes globalization studies into four research clusters: the worldsystems approach, the global culture approach, the global society approach, and the global capitalism approach. He argues that the global capitalism approach is the most productive for theory and research in globalization. Volkmer (1999) has called for the "reformulation or reformatting of existing concepts of international communication" to develop a new theory of global communication that would encompass the "various global movements in shaping the diverse, and...continuously diversifying global communication processes" (p. 2). Gunaratne (2000, 200Ib) has asserted that the "New Global Age" requires more refined global (or macro-level) theories to dissect the reality of the world as an interconnected unit. Chang, Lau, and Hao (2000) have attempted to incorporate various theoretical approaches in inter-national communication research into the world-systems perspective.

As already documented, contemporary scholars have gone well beyond the ideas of Braudel (1967) and Wallerstein (1974) who broached the idea that a worldeconomy - an economy wherein capital accumulation proceeded throughout the world - prevailed in the West since at least the $16^{\text {th }}$ century. ${ }^{2}$ Wallerstein (1979) argued that capitalism as "a system oriented to capital accumulation per se" (p. 272) began in the $16^{\text {th }}$ century. Frank and Gills (1993) discarded the Eurocentric approach of the world-systems theory and adopted a humanocentric approach to socio-historical analysis arguing that a world economy has been in existence for 5,000 years. Castells (1996) pointed out a significant distinction between a world economy and a global economy, stating that the latter signified "an economy with the capacity to work as a unit in real time on a planetary scale" (p. 92).

\section{Triadization}

Louch, Hargittai and Centeno (1999) draw our attention to three dominant interpretations of the process of global interdependence: interdependent globalization (the universal model), civilizations and empires (the clustered model), and hegemonic globalization (the hegemonic model). The universal model presumes a generic and system-wide increase in reciprocal ties between countries. This has been the largely accepted assumption behind much of the discussion of increasing inter-connection. The clustered model presumes an increasing concentration of communication within clusters of countries united by a common cultural

2. Hier (200I) claims that the initial architect of the world-system perspective was Oliver Cox, who produced a trilogy of volumes on capitalism in 1959, 1962, and 1964 tracing the roots of the capitalist system to medieval Venice. 
heritage ${ }^{3}$ or congruent to ex-imperial links, historical flows of trade, and contemporary financial flows. This perspective recognizes clustering around the three major powers-the United States, the European Union, and Japan. The hegemonic model presumes the increasing centrality of a small core of rich countries, perhaps dominated by a single power. This view sees globalization as merely an acceleration of the concentration of resources and influence in European and North American clusters with some limited East Asian additions.

Louch, Hargittai, and Centeno (1999), who tested international telephone traffic from 1983 to 1995 as a measure of "globalization," found little evidence to support the universal model. They found a clear hierarchy of telephone contact mostly concentrated in the wealthiest countries with poorer countries being either marginalized or linked asymmetrically to a cluster of the wealthiest. They also found that the United States had consolidated itself as the "center" with the further weakening of Europe's relative position. In an earlier study, Barnett and Salisbury (1996) traced changes in the international telecommunications network from 1978 to 1992 to examine the process of globalization. Their findings were similar to those of Smith and White (1992), who also found the underlying core-periphery dimension in the world commodity trade flows. At the center were the United States, Western Europe, and Japan; at the periphery were the less-developed countries in Latin America and Africa; and between these two groups were nations generally classified as semiperipheral. This global power configuration, which some scholars identify as "triadization" (Thussu, 2000, p. 77), offers a most tempting meta-theoretical basis for global communication analysis. Mattelart (1996/2000) also identified the construction of the large free-trade economic blocs around the triad powers-North America, East Asia, and the European Union (EU) - as "a major change that has contributed to the creation of new divisions in the world" (p. 98). Bergesen and Sonnett (200I), who analyzed the Global 500, found a very clear three-way split between Asia (29 percent of the firms), Europe (34 percent), and the United States (33 percent), "suggesting a tripartite geopolitical division of the world economy" ( $p$. 1603). Boswell and Chase-Dunn (2000) also recognized the emergence of three regional international economic blocs- the EU, the North American Free Trade

3. This model includes Huntington's (1996) concept of a world system of competing civilizations. Huntington foresees a "clash of civilizations" with the greatest threat coming from Islam and then China. Frank (1998:359) dismisses such concepts as "divisive ideological diatribes... [that] have their intellectual roots in ignorance or denial of a single global history"
Agreement (NAFTA), and the rich Asian economies-to dominate the world economy. Earlier, Galtung and Vincent (1992) had gone to the extent of demarcating the mainly Buddhist-Confucian countries in East Asia and Southeast Asia as a separate world with Japan at the top, and the Four Tigers-South Korea, Taiwan, Hong Kong, and Singapore - in the second tier. The triadization concept also ties in with the socio-historical analysis of Frank (1998:328) who points out that "the globe-encompassing world economy/system did not have a single center but at most a hierarchy of centers" even though a single-centered structure of center-periphery relations prevailed "on intraregional and perhaps on some interregional bases." Frank (1998) also disputes the existence of "semiperipheries" in Wallerstein's sense.

However, some network analysts have disputed the presumed triadization. Barnett and colleagues, who have conducted several international studies on selected aspects of communication - monetary, telecommunication, transportation, and trade flows (Barnett, Salisbury, Kim, \& Langhorne 1999; Salisbury \& Barnett 1999; Barnett, Choi, \& Sun-Miller 1996; Choi \& Ahn 1996; Barnett \& Choi 1995), news flows (Kim \& Barnett 1996), and telephone networks (Sun $\&$ Barnett, 1994) - have concluded that overwhelming empirical findings do not support a triadic world system but a tightly connected group centered on the G-7 countries. Straussfogel (1997), a geographer, on the other hand, describes "the modern world-system as a hierarchically organized complex social structure [comprising] multiple layers of nested and overlapping, cooperating and competing subsystems linked through a variety of types of nonlinear relations" (p. 123). She has proposed the merging of Prigogine's theory of dissipative structures (Prigogine \& Stengers 1984) with world-system theory to derive a framework that is able to account for a large number of spatial and temporal events throughout the history of capitalism.

Castells (1996:145), a sociologist, explained that the new global economy was the outcome of the "interaction between the rise of informationalism and capitalist restructuring." Its characteristics, he said, were interdependence, asymmetry, regionalization, increasing diversification within each region, selective inclusiveness, exclusionary segmentation, and variable geometry (p. 106). Furthermore, he asserted that the architecture of the global economy reflected "an asymmetrically interdependent world," a triad area comprising three major economic regions: North America, with Latin America as its hinterland; Western Europe, with Eastern Europe, Russia and South Mediterranean as its hinterland; Japan and the Asian Pacific (plus Australia and New Zealand), with the rest of Asia, including the Middle East, as its hinterland. He called Africa the marginalized region even though South Africa could be the magnet for the region's resurgence.

Castells (1996) castigated the world-systems theory as "simplistic" because it 
made little analytical sense to compartmentalize the deeply asymmetric global economy into a center, a semiperiphery, and a periphery. He argued that the world has several "centers" and several "peripheries" characterizing the "so internally diversified" North and South (p. I08). Despite Castells' criticism, a triadized configuration of the global center-periphery structure provides a more realistic framework on which to base communication research. In a recent study of 38 countries, $\mathrm{Wu}(2000)$ reported trade volume as the leading predictor in international news coverage. In the light of this finding, the "triadization" model offers a framework to test hypotheses on the news flow within and among the three center-clusters and their respective hinterlands.

Hugill (1999) looked at the geopolitics and technologies of the respective communication systems of Britain, imperial Germany and the United States as they struggled for hegemony. He applied the world-systems perspective but confined himself to the "capitalist world-system only as it has developed over the past 150 years" (p. 16). Despite his Eurocentric approach, Hugill makes a useful assertion: that "in the period of multipolarity we are now entering" (p. I8), the chosen communication strategy of regional power groupings-e.g., NAFTA, the European Union, and Japan-led Asia-will determine their ability to achieve hegemony. This observation further supports the notion of "triadization."

Castells (1996:145) describes the "architecture and geometry of the informational/global economy" as an asymmetrically interdependent phenomenon organized around three major regions-Europe (EU and the European economies affiliated with the Organization for Economic Cooperation and Development), North America (or NAFTA) and the Asian Pacific (Japan and the "China Circle"). He identifies the G-7 countries as "the core of the system" because they accounted for 90.5 percent of high-technology manufacturing in the world (in 1990), and also held 80.4 percent of global computing power. Furthermore, he says that an economic hinterland has sprung up around each of the three major regions with Africa increasingly marginalized in the global economy.

Combining these observations of Castells, Hugill, and others, we can use their triadization framework to empirically observe the information and communication flow among and within the three center-clusters and their respective economic hinterlands. High-technology manufacturing and computing power may serve as the criteria for measuring competitive capital accumulation under informational capitalism. Informational capitalism is what Tehranian (1999) calls "informatic imperialism," which, in his view, is bifurcating the globe into the "high-tech and high-growth centers" and the "disintegrating peripheries" (p. 26). Gunaratne (200Ia) wrote: Where high-technology production and computing power are likely to determine competitive capital accumulation, as well as the concomitant phenomena of hegemony-rivalry and alternating economic cycles, a development approach must recognize the realities of the world/global system. Communication researchers should address this issue to help policy makers stall the proliferation of "disintegrating peripheries."

\section{Triadization Model}

The foregoing review leads us to consider the following essentials for formulating a macro-model for researching aspects related to the global information and communication order.

- Because totalities should be our units of analysis, we should begin with the "collectivist" world system (the capitalist world-economy-in effect, the modern informational economy) as our basic unit of analysis, and only then derive the presence of the "atomistic" states (Bergesen 1990).

- The world system has three center-clusters (Bergesen \& Sonnett 200I; Boswell and Chase-Dunn 2000; Castells 1996; Mattelart, 1996/2000; Smith \& White 1993) one of which occupies the role of the hegemon (Louch, Hargittai \& Centeno 1999) while continuously competing with the other two to maintain its hegemony (Hugill 1999). (Such competition goes hand-in-hand with cooperation in the self-interest of each centercluster as evident in G-7 summits.)

- Each center-cluster has a dependent hinterland of periphery-clusters (Castells 1996), and our subordinate unit of analysis should be these clusters of global states, which have so transformed from nation states as a result of ongoing transnationalization, as well as "financialization" in the informational economy (Bergesen 1990; McMichael 2000; Teivainen 2000).

- These characteristics have made it difficult to study many contemporary problems, which are entangled in global processes, at the level of nation states (Sklair 1999). However, within this structure, we should analyze the phenomena of culture and power (Bergesen 1990), political and cultural effects (Sklair 1999; Chase-Dunn 1999), transnationalization (Teivainen 2000), financialization (McMichael 2000), etc.

\section{Network Model}

Whereas the triadization model is based on attributes of the units comprising the world system, the network model is based on relationships among those units. Hargittai and Centeno (2001:1552) extol the virtues of applying network theory and methods to define "the underlying pattern of the literally millions of sets of ties across the globe." They say network analysis enables precise and concrete means to map the relationships among regions, states, cities or even smaller units. They argue that the two-dimensional perspective reflected in the 
core-periphery structure based on attributes has become irrelevant "in an $N$ dimensional reality," where $N$ represents the number of forms of international reactions. Categorization by attributes, they point out, may miss the "critical dynamics of global cliques" (p. 1551). Within this scheme, the core units are those that emerge as central to these global cliques. However, Chase-Dunn and Grimes (1995:398) say the contention that "network measures are superior to attribute measures has been argued but not demonstrated. The question of method of operationalization is always confounded with the question of the substantive content of the measures."

More recently, several researchers (Barnett 200I; Kick \& Davis 200I; Sacks Ventresca, \& Uzzi 200I; Smith \& Timberlake 200I; Townsend 200I, and Van Rossem 1996) have improved on the earlier work of pioneer "blockmodel" network analysts (Boorman \& White 1976; Breiger 1976; Kick 1987; Knoke \& Kuklinski 1982; Mullins, Hargens, Hecht, \& Kick 1977; Snyder \& Kick 1979) to explore the dynamics of the world-system. Their analyses, accomplished through advanced statistical techniques, have yielded varying core-periphery structures depending on the variables measured. However, the United States and the top G-7 countries in Europe consistently appear as the core though Japan's appearance is inconsistent.

Smith and Timberlake (200I), who studied the hierarchy of world cities based on the international flow of population by air travel, placed Hong Kong and Singapore ahead of Tokyo in 1997 while asserting that the "key cities in Western Europe and North America have continuously maintained their position as central nodes" (p. 1675) even though six or seven East Asian cities had achieved a remarkable rise in importance. Townsend (200I), on the other hand, found in the global structure of the Internet "a shift in the geography of telecommunications networks and the emergence of a network of network cities" ( $p$. I697). Kick and Davis (200I), who conducted a multiple-network analysis of eight types of transnational transactions (trade flows, bilateral economic aid and assistance treaties, bilateral transportation and communication treaties, bilateral sociocultural treaties, bilateral administrative and diplomatic treaties, political conflicts, armament transfers, and military conflicts) for 130 countries during 1970-1975, derived a modified world-system structure: core, semicore (capitalist/ socialist), semiperiphery, and periphery. Kick and Davis concluded that the "core of Western industrial nations," including Japan, dominated the world-system across all the networks (p. I566). No Asian-Pacific country fitted the capitalist semicore although China fitted the socialist semicore. They, however, fitted I2 Asian-Pacific countries, including the East Asian Tigers, in the semiperiphery. Van Rossem (1996), in his role-equivalence model of the world system based on the density of five networks-imports, exports, diplomatic ties, arms trade, and troops, placed highly developed small economies like Iceland, Singapore, Taiwan, and Hong Kong in the second-tier periphery, concluding that "the best proxy for world system role is absolute size of the economy" (p.524).

\section{An integrated model?}

The network model's power to analyze relationships among units constituting the world-system is a clear advantage over linear models based on attributes of those units. However, one must also be aware of its potential pitfalls, which I shall take up in the discussion section of this essay. I take the view that research based on attributes, as well as relations, would serve to validate or discard the findings derived from each method.

\section{CONCEPTS AND METHOD}

This study postulates the transition of the world system into the informational era by grafting the two variables computing power and high-technology manufactures into the trade and exchange mechanism, which determined the center-periphery structure of global states/clusters, according to world-system theory. Castells (1996) identified these two as the crucial variables associated with the dominance of the center-clusters in the modern informational economy. Computing power is a prerequisite for high-technology manufacturing. The ability to compete in high-technology exports, then, determines the center-clusters, as well as the hegemon within them. This study constructed an Informational Society Power Index by combining the two variables, i.e., computing power and high-technology exports, to ascertain the relative dominance of each of the three center-clusters that "triadization" proponents deem to exist.

\section{Computing power}

Glaeser (1997) defined the computing power of a country in terms of million instructions per second (mips) per I,00o people. However, data on mips do not exist for most countries. Therefore, this study settled on two indicators that could generate a reasonable estimate of computing power: the number of personal computers and the number of Internet hosts. Because global states/ clusters can enhance their competitive edge in trade and exchange (e.g., e-commerce) through the global web of computer networks (Gereffi 200I), the number of Internet hosts reflects an important facet of computing power. By combining these two sets of data through an allocation of weights, this study derived a reasonably valid Computing Power Index. International Telecommunication Union (1999) data show that the top io countries (in descending rank order) own 74.3 percent of the world's total number of personal computers. To derive the number of Internet hosts, this study combined two sets of data: the October 
2000 Netsizer estimates for 60 countries $<$ http://www.netsizer.com $>$ and the July 2000 Internet domain survey of the Internet Software Consortium $<\underline{\text { http: }}$ //www.isc.org $>$. It used the ISC data only for the countries not included in the Netsizer list because the latter allocates the three-letter generic Top Level Domains or gTLDs (e.g., com, net, org, edu, gov, mil) to countries on the basis of estimated registrations whereas the ISC does not. These data also show that the top Io countries (in descending rank order) account for 87.8 percent of the world's Internet hosts. ${ }^{4}$ Thus this study allocated a weight of 46 percent $[(74.3$ $\div 162 . \mathrm{I}) \times 100]$ to personal computers and a weight of 54 percent $[(87.8 \div 162 . \mathrm{I}) \times$ IOo] to Internet hosts and added the two results to derive the Computing Power Index. The denominator of these two equations is the sum of the percentages of the top io in each variable $(74.3+87.8=162.1)$. (Microsoft Excel, Microsoft Access, and Minitab were used for the calculations.)

\section{High Technology Exports}

This study used the 1998 high-technology exports data from the World Bank (1999:317), which defines such exports as "goods produced by industries (based on U.S. industry classifications) that rank among a country's Top io in terms of R\&D expenditures."

In simpler terms, high technology exports are products with high $R \& D$ intensity. They include aerospace products, computers, pharmaceuticals, scientific instruments, and electrical machinery (World Bank 2000:307). ${ }^{5}$ National Science Board (2000) says that high-technology industries are important to nations because such industries are associated with (a) innovation, (b) high value-added production and success in foreign markets, and (c) spillover effects that benefit other commercial sectors by generating new products and processes. Data for the I99os show an increased emphasis on high-technology manufactures among the major industrial countries. In 1997, production by U.S. hightechnology industry accounted for nearly 32 percent of world high-technology

4. The top Io countries shared 82.7 percent of the 1999 total of Internet domains, with Japan occupying the ninth rank (Zook 200I). However, Japan occupied the second rank in the share of Internet hosts $<$ http://www.netsizer.com $>$.

5. World Bank (1999:317) identifies high-tech exports, in technical terms, as "commodities in the SITS Revision 2, Sections 5-9 (chemicals and related products, ... manufactures, manufactured articles, machinery and transport equipment, and other manufactured articles and goods not elsewhere classified), excluding Division 68 (nonferrous metals)." OECD identifies four industries as high technology, based on their high R\&D intensities: (a) aerospace, (b) computers and office machinery, (c) electronics-communications, and (d) pharmaceuticals. production, and exports by U.S. high-technology industries accounted for I8.I percent of world high-technology exports. Japan was second, accounting for 9.I percent of exports, followed by the United Kingdom with 8.3 percent (NSB 2000). Because the World Bank excluded the data for Taiwan, an important high-tech product exporter, this study estimated the data by deriving the average for the East Asia region. The data show that the top Io countries (in descending rank order) accounted for 71.I percent of the world's high-tech exports in 1998.

\section{Informational Society Power Index}

This study constructed the ISPI by allocating appropriate weights to the Computing Power Index and the High-Tech Exports Index and, then, combining the two results. It allocated a weight of 53 percent to the CPI $[(78.1 \div 149.2) \times$ IOO] because the top io countries (in descending rank order) accounted for 78.I percent of this index; and it allocated a weight of 47 percent to the HTEI [ 7 I.I $\div$ 149.2) $\times$ IOO] based on the same reasoning. Thus the ISPI, just like its two derivate indexes, gives each global state/cluster a score out of too that reflects its power position in the triadized center-periphery structure.

\section{Reliability and Validity}

Considering the conclusion of Van Rossem (1996) that the absolute size of the economy was the best proxy for world system role, I conducted a regression analysis of the component variables of the ISPI vis-à-vis the Gross National Income of each economy for which relevant data were available. My analysis yielded the following equations: $\mathrm{R}^{2}=82 \%$ for GNI $\mathrm{v}$ high technology exports (using 1999 data for 92 economies); $\mathrm{R}^{2}=82 \%$ for GNI v number of Internet hosts (using $200 \mathrm{I}$ data for $\mathrm{I} 36$ economies); and $\mathrm{R}^{2}=96 \%$ for GNI $\mathrm{v}$ number of PCs (using 2000 data for 116 economies). Thus, we can surmise that all three variables have high reliability, as well as construct validity, because they are significantly anchored to the GNI. The weights allocated to each of these variables - the percentage share of the top Io economies- to construct the ISPI are quite justifiable, though somewhat arbitrary, because of the remarkable dominance of these few economies over each of the three attributes. ${ }^{6}$

6. DeVellis (1991:317) says, "Scale reliability is the proportion of variance attributable to the true score of the latent variable." He clarifies that construct validity is "directly concerned with the theoretical relationship of a variable ... to other variables" (p. 46). As for weights, one could argue that no empirical way exists to determine weights although structural equation (or path) modeling could generate an infinity of statistically accept- 
Table 1 - Regional Pattern of World Merchandise Exports

(based on annual average for 1996-1999)

\begin{tabular}{|c|c|c|c|c|c|c|c|c|}
\hline \multirow[b]{2}{*}{ Origin } & \multirow{2}{*}{$\begin{array}{l}\text { 1996-1999 } \\
\text { Average of } \\
\text { Exports } \\
\text { (\$Billions) } \\
\text { World }\end{array}$} & \multicolumn{7}{|c|}{$\begin{array}{l}\text { Destination } \\
\text { Percentage of exports } \\
\text { (shown along the rows) }\end{array}$} \\
\hline & & $\begin{array}{l}\text { Western } \\
\text { Europe }\end{array}$ & Asia & $\begin{array}{c}\text { North } \\
\text { America }\end{array}$ & $\begin{array}{c}\text { Latin } \\
\text { America }\end{array}$ & $\begin{array}{l}\text { C/E Europe/ } \\
\text { Baltic/CIS }\end{array}$ & $\begin{array}{c}\text { Middle } \\
\text { East }\end{array}$ & Africa \\
\hline World & 5331.75 & $42.1 \%$ & $22.2 \%$ & $20.0 \%$ & $5.4 \%$ & $4.1 \%$ & $2.7 \%$ & $2.2 \%$ \\
\hline Western Europe & 2322.69 & $68.5 \%$ & $8.4 \%$ & $8.7 \%$ & $2.4 \%$ & $5.3 \%$ & $2.6 \%$ & $2.6 \%$ \\
\hline Asia & 1344.57 & $17.5 \%$ & $48.5 \%$ & $24.8 \%$ & $2.6 \%$ & $1.1 \%$ & $2.7 \%$ & $1.5 \%$ \\
\hline North America & 890.44 & $19.1 \%$ & $23.4 \%$ & $37.4 \%$ & $15.2 \%$ & $0.9 \%$ & $2.6 \%$ & $1.3 \%$ \\
\hline Latin America & 278.20 & $14.3 \%$ & $7.4 \%$ & $54.9 \%$ & $19.3 \%$ & $1.1 \%$ & $1.1 \%$ & $1.2 \%$ \\
\hline C/E Europe/Baltic/ClS & 216.74 & $50.7 \%$ & $7.4 \%$ & $4.1 \%$ & $1.7 \%$ & $31.8 \%$ & $2.1 \%$ & $1.2 \%$ \\
\hline Middle East & 163.62 & $20.9 \%$ & $45.6 \%$ & $12.8 \%$ & $1.6 \%$ & $0.8 \%$ & $7.8 \%$ & $4.1 \%$ \\
\hline Africa & 115.96 & $52.5 \%$ & $13.9 \%$ & $15.4 \%$ & $2.7 \%$ & $1.2 \%$ & $1.5 \%$ & $9.1 \%$ \\
\hline
\end{tabular}

Rows show origin; columns show destination.

Boldface indicates exports within each region.

Boldface Oblique indicates exports from periphery clusters to center-clusters.

Source: WTO Annual Report 1999 and 2000 (based on Table A7)

\section{FINDINGS}

The exports-data attribute supported the "triadization" concept. (Statistical advice I received confirmed that tests of significance would make little sense because the data covered the universe.) The 1996-1999 world merchandise trade data (Table I) provided evidence to back the notion of three center-clusters and four dependent periphery-clusters, which Castells (1996) refers to as hinterlands. The process of capital accumulation in the global material economy has generated a scenario where world trade is predominantly concentrated in the three centers: Western Europe ( 42 percent), Asia (22 percent) and North America (20 percent) in that order. In general, most of the Asian continent, including the Middle East, appears to be the binterland of the Asian-Pacific center-Japan and a half-dozen rising economies. ${ }^{7}$ (Almost one-half of Asia's export trade is within

able weights. Wainer and Thissen (1976:9) say "increased robustness can be obtained through the use of equal regression weights without severe loss in accuracy." The weights I have allocated are very close to equal weights.

7. A reader of this manuscript, however, disputed this configuration on the basis of the frequency of telephone calls from the one region to the other. He wrote: "For 1997, Jordan, Kuwait, Oman, Saudi Arabia and UAE do not have an East Asian country among the top 20 nations that they call. But the United States and United Kingdom
Table 2 - The Three Global Centers

\begin{tabular}{lccc}
\hline Global Centers & $\begin{array}{c}\text { Computing } \\
\text { Power Index }\end{array}$ & $\begin{array}{c}\text { High-Tech } \\
\text { Exports Index }\end{array}$ & $\begin{array}{c}\text { Information Society } \\
\text { Power Index }\end{array}$ \\
\hline NAFTA Center & 57.4769 & 24.5170 & 41.9858 \\
EU Center & 18.3091 & 35.9777 & 26.6134 \\
Asian-Pacific Center & 13.3023 & 33.1271 & 22.6200 \\
& $\mathbf{8 9 . 0 8 8 3}$ & 93.6218 & 91.2191 \\
\hline
\end{tabular}

Sources: ITU, 1999; Netsizer, October 2000; ISC, July 2000; World Bank, 1999

Asia, and almost one-half of the Middle East exports go to Asia.) The CentralEastern Europe/NIS region appears to be the hinterland of the Western-Europe center. Because of Africa's heavy dependence on Europe for its meager world trade, Africa also belongs to Europe's binterland. (More than one-half of the exports from the countries in Central and Eastern Europe and the Newly Independent States, as well as more than one-half of the exports of Africa, go to Western Europe.) Finally, Latin America, including the Caribbean, appears to be the binterland of the North-America center. (More than one-half of the exports from Latin America go to North America.).

\section{The Triad}

This study defined the North-America center as the NAFTA cluster of global states, the Western-Europe center as the EU cluster of global states, and the Asian-Pacific center as the cluster of eight global states that topped the region's Information Society Power Index (i.e., Japan, Singapore, South Korea, China, Taiwan, Malaysia, Philippines, and Australia). These three center-clusters scored 9I.2 out of the maximum possible Ioo on the ISPI, thereby showing their remarkable dominance over their hinterlands (Table 2). NAFTA was the hegemon of the center-clusters with a score of 42 . The EU, with a score of 26.6, was slightly ahead of the Asian-Pacific center with 22.6. Figure I illustrates the

are among the top Io." Considering that 46 percent of Middle East's trade is with Asia (World Trade Organization 1999), this may mean that the trading partners are not using telephone communication alone for trade transactions because of language problems. The Middle East also has considerable trade connections with Western Europe (2I percent) and North America (13 percent). Trade data for 1997 clearly show that Japan was the No. I market for exports from Kuwait, Oman, Saudi Arabia, and UAE (International Monetary Fund 1998). Telephone communication data may well be a reflection of the international language order that has elevated English as the global language, and also of the Middle Eastern diaspora in the EU and the NAFTA center-clusters. 
Figure 1 - Center Clusters and Hinterlands

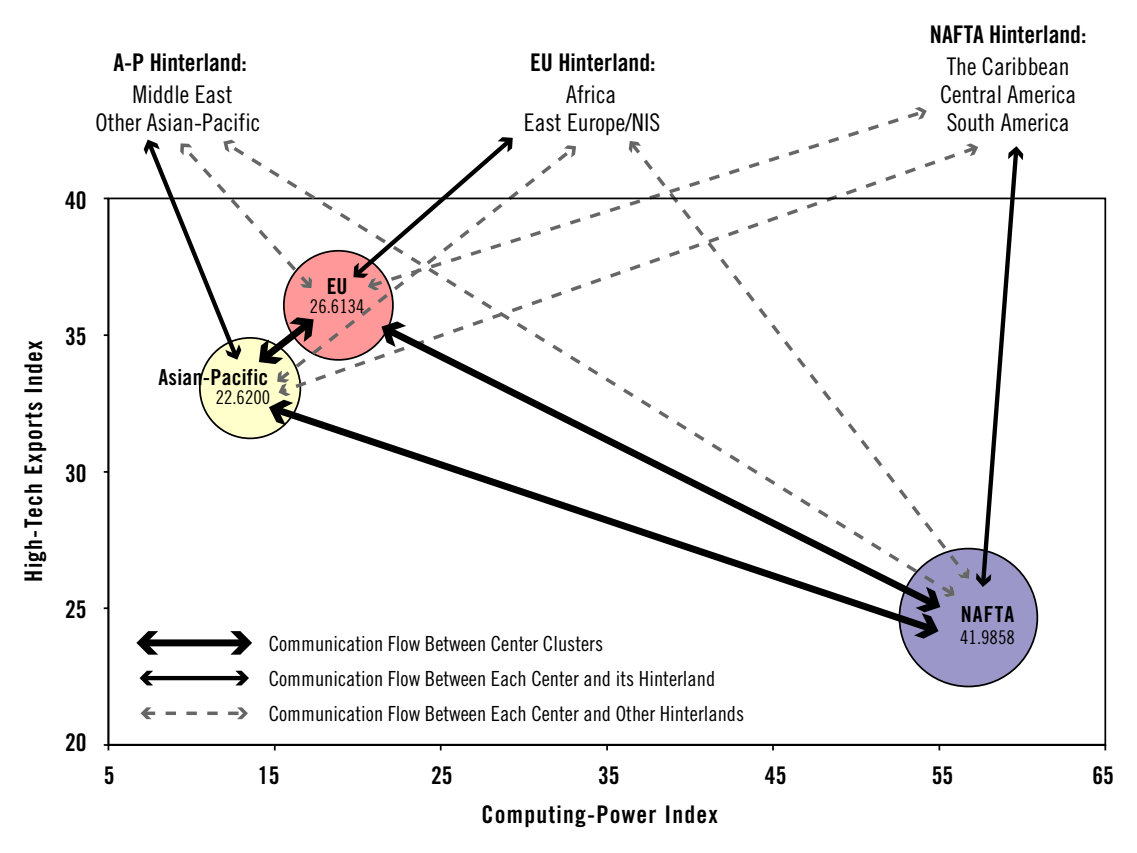

Note: Size of Bubble = Information Society Power Index

relative size of the three center-clusters in relation to the ISPI, as well as their relative positions on the two derivate indexes-the CPI and the HTEI.

\section{NAFTA Center}

Within the hegemon cluster, the United States stands out as the super global state with an ISPI score of 38. Canada and Mexico have relatively little power within the cluster (Table 3 and Figure 2). Because the United States beats the ISPI score of each of the other center-clusters, its influence on the entire world system becomes crystal clear. As a macro-unit, the NAFTA Center has a population of 4IO.3 million, a gross "national" income of \$10.7 trillion, and a per capita income of $\$ 26,188$ (World Bank 2000).

\section{EU Center}

Three global states stand out in the EU cluster: Germany and the United Kingdom hold the lead, with France closely behind. The Netherlands and Italy occupy the middle between the Big Three and the other Io global states of the cluster (Table 4 and Figure 3). As a macro-unit, the EU Center has a population
Table 3 - Components of NAFTA-Center

\begin{tabular}{lrcc}
\hline NAFTA-Center & $\begin{array}{c}\text { Computing } \\
\text { Power Index }\end{array}$ & $\begin{array}{c}\text { High-Tech } \\
\text { Exports Index }\end{array}$ & $\begin{array}{c}\text { Information Society } \\
\text { Power Index }\end{array}$ \\
\hline United States & 53.6910 & 19.7682 & 37.7473 \\
Canada & 3.0831 & 2.5175 & 2.8172 \\
Mexico & 0.7028 & 2.2314 & 1.4212 \\
Sub-total & $\mathbf{5 7 . 4 7 6 9}$ & 24.5170 & 41.9858 \\
\hline
\end{tabular}

Sources: ITU, 1999; Netsizer, October 2000; ISC, July 2000; World Bank, 1999

\section{Figure 2 - Center Cluster NAFTA}

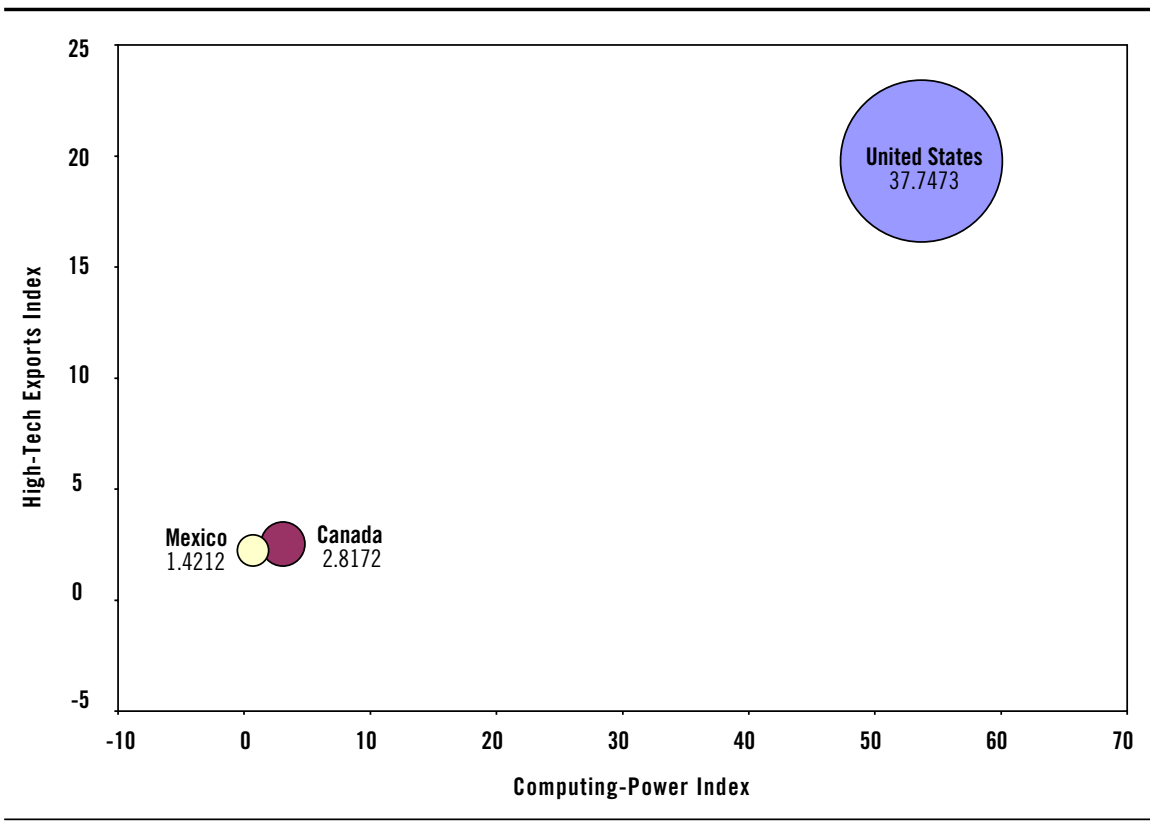

Note: Size of Bubble $=$ Information Society Power Index

of 376.4 million, a gross "national" income of $\$ 8.5$ trillion, and a per capita income of $\$ 22,654$ (World Bank 2000).

\section{Asian-Pacific Center}

Compared with the other two, the Asian-Pacific center-cluster is geographically not contiguous. Japan leads it with an ISPI score of 8.6 followed by Singapore (Table 5 and Figure 4). Except for Japan, South Korea and Australia, the other global states of this center-cluster do not belong to the OECD-the 


\section{Table 4 - Components of EU-Center}

\begin{tabular}{lccc}
\hline EU-Center & $\begin{array}{c}\text { Computing } \\
\text { Power Index }\end{array}$ & $\begin{array}{c}\text { High-Tech } \\
\text { Exports Index }\end{array}$ & $\begin{array}{c}\text { Information Society } \\
\text { Power Index }\end{array}$ \\
\hline Germany & 4.1885 & 7.3775 & 5.6873 \\
United Kingdom & 3.6339 & 7.4658 & 5.4349 \\
France & 2.1544 & 6.2754 & 4.0913 \\
Netherlands & 1.3734 & 4.0973 & 2.6537 \\
Italy & 2.3314 & 1.9766 & 2.1646 \\
Ireland & 0.1997 & 2.7732 & 1.4092 \\
Sweden & 0.9500 & 1.5896 & 1.2506 \\
Belgium & 0.6005 & 1.2873 & 0.9233 \\
Spain & 0.9080 & 0.6526 & 0.7880 \\
Finland & 0.6479 & 0.9409 & 0.7856 \\
Austria & 0.4852 & 0.6807 & 0.5771 \\
Denmark & 0.4768 & 0.6346 & 0.5510 \\
Portugal & 0.1796 & 0.0940 & 0.1394 \\
Greece & 0.1516 & 0.0489 & 0.1033 \\
Luxembourg & 0.0280 & $0.0832^{*}$ & $0.0540^{*}$ \\
Sub-total & 18.3091 & 35.9777 & 26.6134 \\
\hline
\end{tabular}

Sources: ITU, 1999; Netsizer, October 2000; ISC, July 2000; World Bank, 1999 * Estimated

\section{Figure 3 - Center Cluster: European Union}

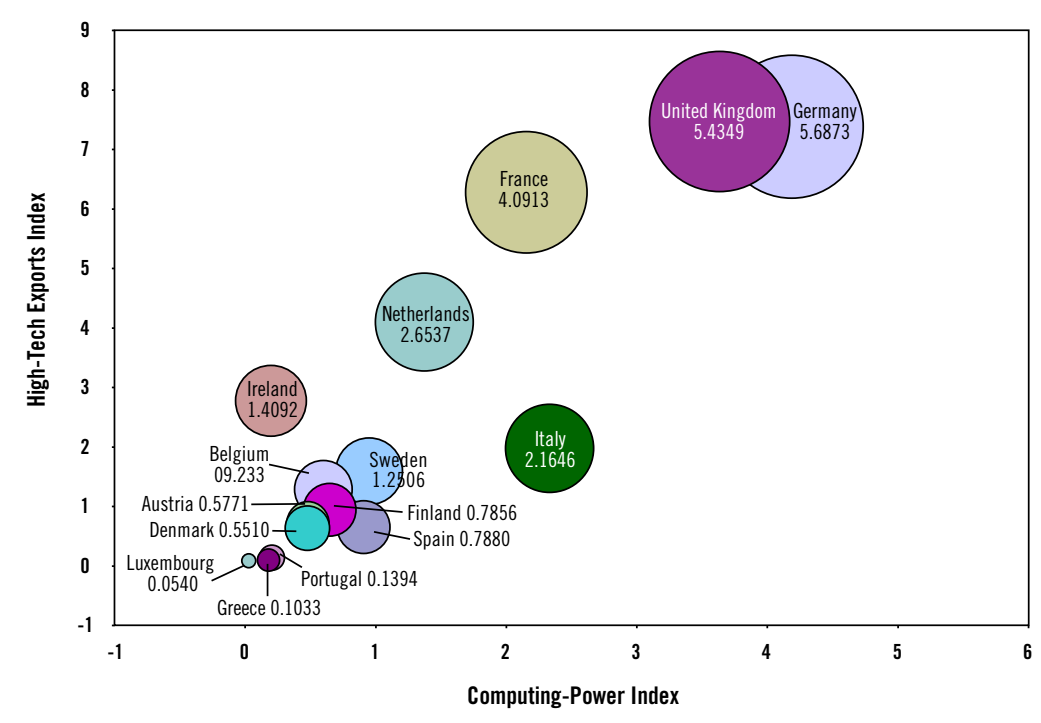

Note: Size of Bubble = Information Society Power Index
Table 5 - Components of Asian-Pacific Center

\begin{tabular}{lccc}
\hline Asian-Pacific Center & $\begin{array}{c}\text { Computing } \\
\text { Power Index }\end{array}$ & $\begin{array}{c}\text { High-Tech } \\
\text { Exports Index }\end{array}$ & $\begin{array}{c}\text { Information Society } \\
\text { Power Index }\end{array}$ \\
\hline Japan & 6.5504 & 10.9770 & 8.6309 \\
Singapore & 0.3179 & 6.3449 & 3.1506 \\
Korea, South & 1.2767 & 3.5420 & 2.3414 \\
China & 1.8865 & 2.6995 & 2.2686 \\
Taiwan & 1.0570 & $3.5538^{*}$ & $2.2305^{\star}$ \\
Malaysia & 0.2158 & 3.6389 & 1.8247 \\
Philippines & 0.1630 & 2.1898 & 1.1156 \\
Australia & 1.8349 & 0.1811 & 1.0576 \\
Sub-Total & 13.3023 & 33.1270 & 22.6200 \\
\hline
\end{tabular}

Sources: ITU, 1999; Netsizer, October 2000; ISC, July 2000; World Bank, 1999

* Estimated

\section{Figure 4 - Center Cluster: Asian-Pacific}

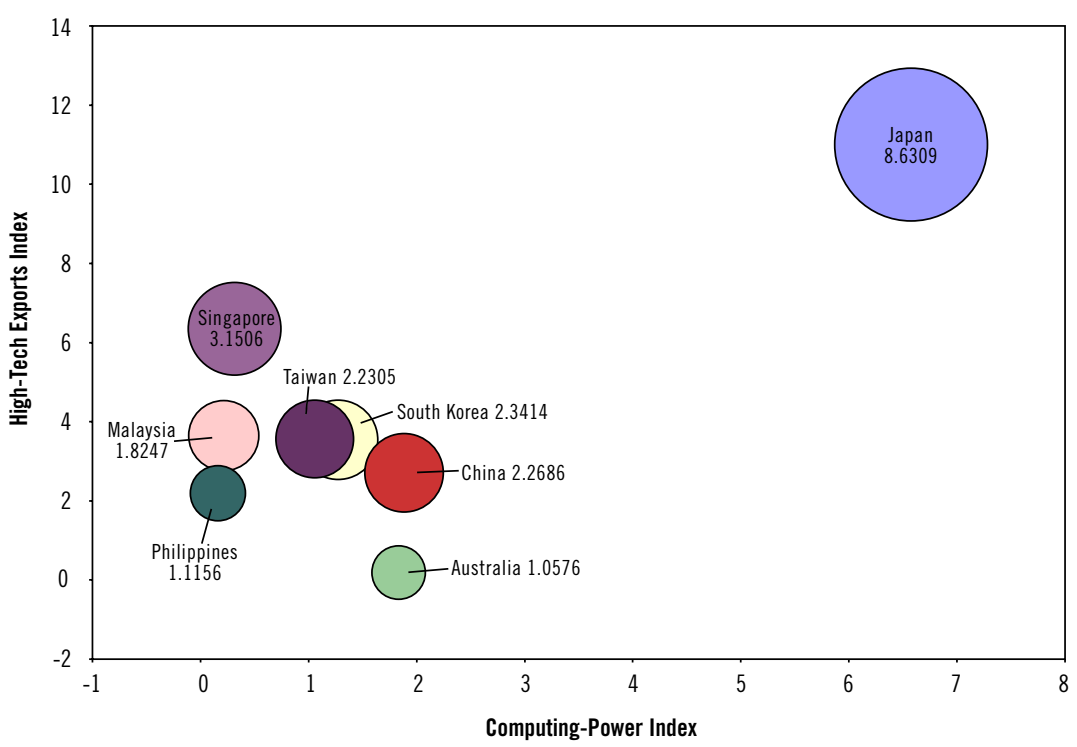

Note: Size of Bubble $=$ Information Society Power Index

world's club of the rich. New Zealand, an OECD member, is not included in this cluster. Hong Kong also is not included although one could justify its inclusion as part of China. Unlike the other two center-clusters, the Asia-Pacific centercluster is neither an economic union nor a free-trade association. As a macro- 
Table 6 - OECD-Member Countries

\begin{tabular}{|c|c|c|c|}
\hline OECD Countries & $\begin{array}{l}\text { Computing } \\
\text { Power Index }\end{array}$ & $\begin{array}{l}\text { High-Tech } \\
\text { Exports Index }\end{array}$ & $\begin{array}{l}\text { Information Society } \\
\text { Power Index }\end{array}$ \\
\hline United States & 53.6910 & 19.7682 & 37.7473 \\
\hline Japan & 6.5504 & 10.9770 & 8.6309 \\
\hline Germany & 4.1885 & 7.3775 & 5.6873 \\
\hline United Kingdom & 3.6339 & 7.4658 & 5.4349 \\
\hline France & 2.1544 & 6.2754 & 4.0913 \\
\hline Canada & 3.0831 & 2.5175 & 2.8172 \\
\hline Netherlands & 1.3734 & 4.0973 & 2.6537 \\
\hline Korea, South & 1.2767 & 3.5420 & 2.3414 \\
\hline Italy & 2.3314 & 1.9766 & 2.1646 \\
\hline Mexico & 0.7028 & 2.2314 & 1.4212 \\
\hline Ireland & 0.1997 & 2.7732 & 1.4092 \\
\hline Sweden & 0.9500 & 1.5896 & 1.2506 \\
\hline Australia & 1.8349 & 0.1811 & 1.0576 \\
\hline Switzerland & 0.6388 & 1.3933 & 0.9934 \\
\hline Belgium & 0.6005 & 1.2873 & 0.9233 \\
\hline Spain & 0.9080 & 0.6526 & 0.7880 \\
\hline Finland & 0.6479 & 0.9409 & 0.7856 \\
\hline Austria & 0.4852 & 0.6807 & 0.5771 \\
\hline Denmark & 0.4768 & 0.6346 & 0.5510 \\
\hline Norway & 0.5251 & 0.2188 & 0.3811 \\
\hline Hungary & 0.1679 & 0.4507 & 0.3008 \\
\hline Poland & 0.4589 & 0.0792 & 0.2805 \\
\hline Czech Republic & 0.2037 & 0.2294 & 0.2158 \\
\hline Turkey & 0.3595 & 0.0515 & 0.2148 \\
\hline New Zealand & 0.3342 & 0.0546 & 0.2028 \\
\hline Portugal & 0.1796 & 0.0940 & 0.1394 \\
\hline Greece & 0.1516 & 0.0489 & 0.1033 \\
\hline Luxembourg & 0.0280 & $0.0832^{*}$ & $0.0539 *$ \\
\hline Slovak Republic & 0.0659 & 0.0335 & 0.0507 \\
\hline Iceland & 0.0325 & $0.0425^{*}$ & $0.0372^{*}$ \\
\hline Grand Total & 88.2347 & 77.7483 & 83.3061 \\
\hline
\end{tabular}

Sources: ITU, 1999; Netsizer, October 2000; ISC, July 2000; World Bank, 1999

* Estimated

unit, the Asian-Pacific Center has a population of I.6 billion, a gross "national" income of $\$ 6.8$ trillion, and a per capita income of $\$ 4,200$ (World Bank 2000).

\section{OECD}

The traditional world-system perspective would most likely see the 30 member states of the Organization of Economic Cooperation and Development
(OECD) as the units comprising the world's center and the semiperiphery. The Group of Seven (G-7), the world's super-rich countries, would be the center, and the remainder the semiperiphery. My analysis shows that the OECD cluster accounts for 83.3 percent of the ISPI (Table 6).

\section{Geographical Breakdowns}

Table 7 shows the power rankings, in descending order, of each of the traditionally recognized main geographical regions. The Americas head the list followed by Western Europe, Asia-Pacific, East/Central Europe and the Newly Independent States, Middle East, and Africa. It also shows the power rankings of the sub-regions comprising each major region. Nested within each sub-region are the power rankings of each of its principal global states. The data in this table can assist the researchers who may want to redefine center-clusters and periphery-clusters.

\section{DISCUSSION}

Although the world merchandise trade data help us identify the clusters comprising the global triad, they do not help us to correctly identify the hegemon of these three center-clusters. With 42 percent of the world trade concentrated in Western Europe, one could mistakenly identify the EU center-cluster as the hegemon. (IMF data for 1997 show that 60.6 percent of EU exports went to other EU countries, 8.7 percent to NAFTA, and 7.5 percent to Asian-Pacific core. See Table I for the three-year average for Western Europe.) However, the Information Society Power Index, which highlights the two main resources that presumably engender power inequalities among states, enables one to identify the actual hegemon. ${ }^{8}$ In Wallerstein's parlance, a new world-economy, which Castells calls an informational economy, has replaced the old world-economy. In my formulation of the world system, the three center-clusters would include many, though not all, of the global states that Wallerstein placed in the semiperiphery. Thus, prosperous small global states too have become part of the center. This perspective differs from that of Van Rossem (1996), who placed highly developed small economies in the second-tier periphery in his role-equivalence model of the world system. However, he allowed that global states could "gain

8. If one were to add up the exports and imports within the 50 states comprising the United States, just as in the case of the 15 components of the European Union, the result would also pinpoint the actual hegemon by smoothening the "inflated" share of world merchandise trade credited to the latter. 
Table 7 - Relative Standing of Countries within Subregions of Major World Regions

\begin{tabular}{|c|c|c|c|}
\hline & 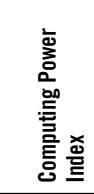 & 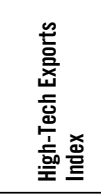 & 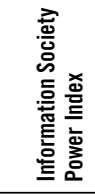 \\
\hline Americas & 59.5676 & 24.9745 & 43.3088 \\
\hline North & 57.4769 & 24.5170 & 41.9858 \\
\hline United States & 53.6910 & 19.7682 & 37.7473 \\
\hline Canada & 3.0831 & 2.5175 & 2.8172 \\
\hline Mexico & 0.7028 & 2.2314 & 1.4212 \\
\hline South & 1.9876 & 0.4187 & 1.2502 \\
\hline Brazil & 1.0081 & 0.2958 & 0.6733 \\
\hline Argentina & 0.3241 & 0.0569 & 0.1985 \\
\hline Colombia & 0.1915 & 0.0351 & 0.1180 \\
\hline Chile & 0.1531 & 0.0107 & 0.0861 \\
\hline Venezuela & 0.1362 & 0.0091 & 0.0765 \\
\hline Peru & 0.0637 & 0.0041 & 0.0357 \\
\hline Uruguay & 0.0593 & 0.0025 & 0.0326 \\
\hline Ecuador & 0.0308 & 0.0023 & 0.0174 \\
\hline Bolivia & 0.0126 & 0.0017 & 0.0075 \\
\hline Paraguay & 0.0081 & 0.0005 & 0.0045 \\
\hline Central & 0.0754 & 0.0382 & 0.0579 \\
\hline Costa Rica & 0.0235 & 0.0256 & 0.0245 \\
\hline Guatemala & 0.0147 & 0.0069 & 0.0110 \\
\hline El Salvador & 0.0124 & 0.0052 & 0.0090 \\
\hline Panama & 0.0123 & 0.0000 & 0.0065 \\
\hline Honduras & 0.0072 & 0.0002 & 0.0039 \\
\hline Nicaragua & 0.0053 & 0.0002 & 0.0029 \\
\hline Caribbean & 0.0276 & 0.0006 & 0.0149 \\
\hline Jamaica & 0.0134 & 0.0001 & 0.0072 \\
\hline Cuba & 0.0097 & 0.0000 & 0.0052 \\
\hline Dominican Republic & 0.0039 & 0.0002 & 0.0022 \\
\hline Puerto Rico & 0.0006 & 0.0000 & 0.0003 \\
\hline Haiti & 0.0000 & 0.0002 & 0.0001 \\
\hline Western Europe & 19.4450 & 37.5066 & 27.9339 \\
\hline Big Five & 13.2162 & 23.7480 & 18.1661 \\
\hline Germany & 4.1885 & 7.3775 & 5.6873 \\
\hline United Kingdom & 3.6339 & 7.4658 & 5.4349 \\
\hline France & 2.1544 & 6.2754 & 4.0913 \\
\hline Italy & 2.3314 & 1.9766 & 2.1646 \\
\hline Spain & 0.9080 & 0.6526 & 0.7880 \\
\hline Smaller Countries & 3.6290 & 10.3748 & 6.7995 \\
\hline Netherlands & 1.3734 & 4.0973 & 2.6537 \\
\hline Ireland & 0.1997 & 2.7732 & 1.4092 \\
\hline Switzerland & 0.6388 & 1.3933 & 0.9934 \\
\hline Belgium & 0.6005 & 1.2873 & 0.9233 \\
\hline
\end{tabular}

\begin{tabular}{|c|c|c|c|}
\hline & 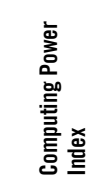 & 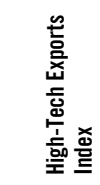 & 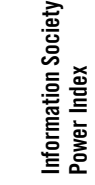 \\
\hline Austria & 0.4852 & 0.6807 & 0.5771 \\
\hline Portugal & 0.1796 & 0.0940 & 0.1394 \\
\hline Greece & 0.1516 & 0.0489 & 0.1033 \\
\hline Nordic & 2.5998 & 3.3839 & 2.9683 \\
\hline Sweden & 0.9500 & 1.5896 & 1.2506 \\
\hline Finland & 0.6479 & 0.9409 & 0.7856 \\
\hline Denmark & 0.4768 & 0.6346 & 0.5510 \\
\hline Norway & 0.5251 & 0.2188 & 0.3811 \\
\hline Asia-Pacific & 15.1259 & 35.5903 & 24.7441 \\
\hline East Asia & 11.2112 & 21.3226 & 15.9636 \\
\hline Japan & 6.5504 & 10.9770 & 8.6309 \\
\hline Korea, South & 1.2767 & 3.5420 & 2.3414 \\
\hline China & 1.8865 & 2.6995 & 2.2686 \\
\hline Taiwan & 1.0570 & 3.5538 & 2.2305 \\
\hline Hong Kong & 0.4384 & 0.5503 & 0.4910 \\
\hline Mongolia & 0.0021 & 0.0000 & 0.0011 \\
\hline South East Asia & 1.2206 & 13.8784 & 7.1698 \\
\hline Singapore & 0.3179 & 6.3449 & 3.1506 \\
\hline Malaysia & 0.2158 & 3.6389 & 1.8247 \\
\hline Philippines & 0.1630 & 2.1898 & 1.1156 \\
\hline Thailand & 0.1982 & 1.4592 & 0.7909 \\
\hline Indonesia & 0.2335 & 0.2455 & 0.2391 \\
\hline Vietnam & 0.0832 & 0.0000 & 0.0441 \\
\hline Myanmar & 0.0059 & 0.0000 & 0.0032 \\
\hline Cambodia & 0.0017 & 0.0000 & 0.0009 \\
\hline Laos & 0.0014 & 0.0000 & 0.0008 \\
\hline Oceania & 2.1693 & 0.2357 & 1.2605 \\
\hline Australia & 1.8349 & 0.1811 & 1.0576 \\
\hline New Zealand & 0.3342 & 0.0546 & 0.2028 \\
\hline Papua New Guinea & 0.0002 & 0.0000 & 0.0001 \\
\hline South Asia & 0.5247 & 0.1536 & 0.3503 \\
\hline India & 0.4162 & 0.1522 & 0.2921 \\
\hline Pakistan & 0.0719 & 0.0010 & 0.0386 \\
\hline Bangladesh & 0.0154 & 0.0003 & 0.0084 \\
\hline Sri Lanka & 0.0136 & 0.0000 & 0.0072 \\
\hline Nepal & 0.0076 & 0.0000 & 0.0040 \\
\hline East-Central Europe/NIS & 2.2061 & 1.2506 & 1.7570 \\
\hline East Central & 0.8964 & 0.7928 & 0.8477 \\
\hline Hungary & 0.1679 & 0.4507 & 0.3008 \\
\hline Poland & 0.4589 & 0.0792 & 0.2805 \\
\hline Czech Republic & 0.2037 & 0.2294 & 0.2158 \\
\hline Slovak Republic & 0.0659 & 0.0335 & 0.0507 \\
\hline
\end{tabular}




\begin{tabular}{|c|c|c|c|}
\hline & 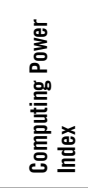 & 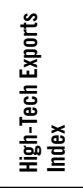 & 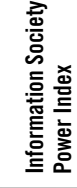 \\
\hline NIS & 1.0310 & 0.3579 & 0.7147 \\
\hline Russia & 0.7959 & 0.2836 & 0.5552 \\
\hline Ukraine & 0.1129 & 0.0000 & 0.0598 \\
\hline Estonia & 0.0456 & 0.0200 & 0.0336 \\
\hline Lithuania & 0.0330 & 0.0082 & 0.0213 \\
\hline Latvia & 0.0295 & 0.0049 & 0.0179 \\
\hline Belarus & 0.0006 & 0.0236 & 0.0114 \\
\hline Kazakhstan & 0.0023 & 0.0119 & 0.0068 \\
\hline Moldova & 0.0053 & 0.0013 & 0.0034 \\
\hline Kyrgyzstan & 0.0016 & 0.0036 & 0.0025 \\
\hline Armenia & 0.0031 & 0.0007 & 0.0020 \\
\hline Georgia & 0.0006 & 0.0000 & 0.0003 \\
\hline Turkmenistan & 0.0003 & 0.0000 & 0.0001 \\
\hline Azerbaijan & 0.0001 & 0.0000 & 0.0001 \\
\hline Uzbekistan & 0.0001 & 0.0000 & 0.0001 \\
\hline Tajikistan & 0.0001 & 0.0000 & 0.0001 \\
\hline Southeast & 0.2786 & 0.1000 & 0.1946 \\
\hline Slovenia & 0.0732 & 0.0413 & 0.0582 \\
\hline Romania & 0.0866 & 0.0136 & 0.0522 \\
\hline Croatia & 0.0459 & 0.0308 & 0.0388 \\
\hline Bulgaria & 0.0353 & 0.0129 & 0.0248 \\
\hline Yugoslavia & 0.0338 & 0.0000 & 0.0179 \\
\hline Albania & 0.0024 & 0.0001 & 0.0013 \\
\hline Macedonia & 0.0013 & 0.0013 & 0.0013 \\
\hline Middle East & 1.4990 & 0.5569 & 1.0562 \\
\hline West Asia & 1.4990 & 0.5569 & 1.0562 \\
\hline Israel & 0.3014 & 0.4921 & 0.3910 \\
\hline Iran & 0.4163 & 0.0000 & 0.2206 \\
\hline Turkey & 0.3595 & 0.0515 & 0.2148 \\
\hline United Arab Emirates & 0.1769 & 0.0000 & 0.0938 \\
\hline Saudi Arabia & 0.1444 & 0.0045 & 0.0787 \\
\hline Kuwait & 0.0298 & 0.0010 & 0.0163 \\
\hline Syria & 0.0273 & 0.0000 & 0.0145 \\
\hline Lebanon & 0.0205 & 0.0000 & 0.0109 \\
\hline Oman & 0.0081 & 0.0076 & 0.0079 \\
\hline Jordan & 0.0111 & 0.0000 & 0.0059 \\
\hline Yemen & 0.0036 & 0.0000 & 0.0019 \\
\hline Iraq & 0.0000 & 0.0000 & 0.0000 \\
\hline Africa & 0.8109 & 0.1289 & 0.4904 \\
\hline Southern Africa & 0.4717 & 0.1105 & 0.3019 \\
\hline South Africa & 0.4017 & 0.1069 & 0.2631 \\
\hline Zimbabwe & 0.0195 & 0.0015 & 0.0111 \\
\hline Mauritius & 0.0148 & 0.0017 & 0.0087 \\
\hline Zambia & 0.0082 & 0.0000 & 0.0043 \\
\hline Namibia & 0.0078 & 0.0000 & 0.0041 \\
\hline
\end{tabular}

\begin{tabular}{|c|c|c|c|}
\hline & 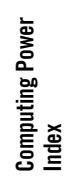 & 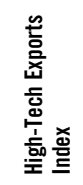 & 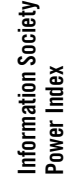 \\
\hline Botswana & 0.0072 & 0.0000 & 0.0038 \\
\hline Mozambique & 0.0060 & 0.0002 & 0.0033 \\
\hline Madagascar & 0.0039 & 0.0001 & 0.0021 \\
\hline Angola & 0.0014 & 0.0000 & 0.0008 \\
\hline Malawi & 0.0012 & 0.0000 & 0.0006 \\
\hline Lesotho & 0.0000 & 0.0000 & 0.0000 \\
\hline North Africa & 0.1668 & 0.0139 & 0.0949 \\
\hline Egypt & 0.0919 & 0.0002 & 0.0488 \\
\hline Morocco & 0.0362 & 0.0010 & 0.0197 \\
\hline Tunisia & 0.0173 & 0.0120 & 0.0148 \\
\hline Algeria & 0.0214 & 0.0006 & 0.0116 \\
\hline Libya & 0.0000 & 0.0000 & 0.0000 \\
\hline West Africa & 0.1275 & 0.0022 & 0.0686 \\
\hline Nigeria & 0.0832 & 0.0000 & 0.0441 \\
\hline Senegal & 0.0169 & 0.0000 & 0.0090 \\
\hline Ghana & 0.0060 & 0.0000 & 0.0032 \\
\hline Cameroon & 0.0048 & 0.0002 & 0.0026 \\
\hline Togo & 0.0042 & 0.0000 & 0.0022 \\
\hline Guinea & 0.0036 & 0.0000 & 0.0019 \\
\hline Gabon & 0.0014 & 0.0020 & 0.0017 \\
\hline Mauritania & 0.0019 & 0.0000 & 0.0010 \\
\hline Mali & 0.0013 & 0.0000 & 0.0007 \\
\hline Chad & 0.0012 & 0.0000 & 0.0006 \\
\hline Benin & 0.0011 & 0.0000 & 0.0006 \\
\hline Gambia & 0.0006 & 0.0000 & 0.0003 \\
\hline Central African Republic & 0.0006 & 0.0000 & 0.0003 \\
\hline Niger & 0.0005 & 0.0000 & 0.0003 \\
\hline Sierra Leone & 0.0000 & 0.0000 & 0.0000 \\
\hline Guinea-Bissau & 0.0000 & 0.0000 & 0.0000 \\
\hline East Africa & 0.0450 & 0.0023 & 0.0249 \\
\hline Kenya & 0.0170 & 0.0023 & 0.0101 \\
\hline Sudan & 0.0083 & 0.0000 & 0.0044 \\
\hline Tanzania & 0.0074 & 0.0000 & 0.0039 \\
\hline Uganda & 0.0066 & 0.0000 & 0.0035 \\
\hline Ethiopia & 0.0054 & 0.0000 & 0.0029 \\
\hline Rwanda & 0.0002 & 0.0000 & 0.0001 \\
\hline Eritrea & 0.0000 & 0.0000 & 0.0000 \\
\hline Burundi & 0.0000 & 0.0000 & 0.0000 \\
\hline Grand Total & 98.65 & 100 & 99.29 \\
\hline
\end{tabular}

Sources: ITU, 1999; Netsizer, October 2000; ISC, July 2000; World Bank, 1999 
prominence in the world system through cooperation and regional alliances that pool their resources" (p.524).

Adhering to Bergesen (1990), I began with the international order and only then derived the presence of states and national economies. My starting point was the global trade flow pattern, which enabled me to determine the regional clusters that dominated the world economy/system. (However, my configuration was based on the pattern of exports, not imports, because exports represent the competition for world capital accumulation. The relational data derived from network analysis would reflect both exports and imports but with inadequate attention to the magnitude of trade.) Then I hypothesized the factors - computing power and high-technology manufacturing-that enabled these clusters to compete successfully in the global informational economy. Thereafter, I looked at the pattern of distribution of the world totality of computing power and high-tech exports to construct a power index for each center-cluster and its constituent member states. My approach of using attributes for analysis is consistent with that of historical social science that gave birth to the world-systems theory.

As pointed out earlier, adherents of network theory, including Barnett et al. (1999), assert that the proper approach to the analysis of structural theory uses relational data such as the frequency of communication among social systems or nation states. However, network analysis also suffers from major drawbacks. First, the lack of global data sets makes it an impractical method to uncover the historical center-periphery structure of the world economy going back at least to the beginning of the European Age (Wallerstein 1974) or the Asian Age (Frank 1998). Smith and Timberlake (200I) confess "the lack of data on the flows between any units of a network means that relational analysis can never adequately capture its multiplex structure in totality" (p+1662), and the nature of network analysis made "missing data particularly problematic" (p. I66I). Second, in the absence of solid and unbiased data sets encompassing all global units, network analysis based on partial data will raise questions on validity in spite of statistically derived results on connectedness, centrality, and integrativeness. Although some good network data on commodity trade flows are available, Smith and Timberlake lament the "absolute dearth of relational data on all social phenomena" (p. I66I), i.e., compilations of networks of interactions or flows between global units. In relation to tracing communication networks, Smith and Timberlake point out that although sampling the volume of telephone calls, telex messages, faxes, telegraph, and mail is possible in principle, telephone companies "would probably be reluctant to share such information because of the possible implications for their competitive positions in the industry" (p. I663). Third, the dearth of data available for network analysis forces researchers to operationalize research concepts to suit the availability of data thereby raising further questions on validity. ${ }^{9}$ For instance, Kim and Barnett (1996) used the country reports of international newspapers and periodicals trade data-a very narrow category based on self-reporting - to define news flows. Again, Barnett et al. (1999) used data from a U.S.-based credit card corporation to measure global monetary flows that gave an incomplete picture of international transactions related to Japan in particular.

This study has hypothesized that the power structure of the Information Society, to a large extent, is dependent on computing power and high-technology manufacturing. However, one should be conscious that these two variables, in turn, are the consequence of a cluster of antecedent variables, such as those included in the Human Development Index (United Nations Development Program 2000) - the real per capita income, literacy, education, and life expectancy. The emphasis placed on research and development is also a supremely important factor. The Computing Power Index constructed for this study needs further validation through a comparison with mips (million instructions per second) when such data become available for most global clusters. Furthermore, the reliability of the CPI also depends on the accuracy of the estimates of the number of personal computers and Internet hosts. This study's High Technology Exports Index also needs refinement based on a "more comprehensive notion of high technology" (Chabot c. 1996).

This study provides the following world system perspective. The modern world-economy comprises three competing center-clusters, each of which has a dependent hinterland of periphery-clusters. The relative power of the three center-clusters is unequal. Among them, there is a hegemon cluster led by a global state that has more power in the world system than any other. The relative power of the global states within the center-clusters, as well as those within the periphery-clusters, is also unequal. If one were to presume that the global information and communication flow follows the pattern of this triadized centerhinterland structure, this reformulated world system perspective offers a rich theoretical framework for conducting global communication research.

Barnett and colleagues, as noted earlier, say their network analyses do not show a triadic configuration as postulated by Castells (I996), Mattelart (1996/ 2000), and others. Barnett and Choi (1995), however, say they found three groupings of a different kind: a Spanish-language based group that included Spain and Latin America; an English-language based group that included East and South

9. Van Rossem (1996:525) says, "The development of better measures of world system role is made difficult not only by the conceptual confusion, but also by the poor quality and limited availability of international data." 
Asia, the Middle East, Africa, Ireland, the United Kingdom, the United States and Canada; and a group comprising continental Europe, excluding France and Spain. The Barnett team's Choi and Ahn (1996) confirmed the centrality of the G-7 countries in Europe but found no evidence (Choi \& Ahn 1994) of the centrality of Japan in the Pacific Basin community. They placed Hong Kong, as the center of information flow in East Asia. Although WTO data on world trade (Table I) clearly indicate the triadic domination of the world economy, Barnett et al. (1999) provide no explanation for this discrepancy. They assert:

When comparing the international monetary, telecommunications and trade networks, the overall results suggest these three networks are quite similar. NEGOPY results suggest that these networks share similar core, peripheral, semi-peripheral and marginal countries.... In spite of all the recent ideological criticisms of the world system theory..., these research findings support the theory....The consistent regional patterns of organization in the three networks suggest a further anomaly in the world system theory, i.e., factors other than economic ones determine the structure of the world system. These include geographical and cultural factors. (Barnett et al. 1999:43)

Barnett and Choi (1995) and Barnett and Salisbury (1996), however, did find regional clusters for telecommunication flows, as well as for international telephone use. Barnett et al. (1999:42) admitted that these were "somewhat at odds with world system theory." They said that one explanation could be that the world system may be divided into regional groupings even though "recent research has failed to confirm this finding for international trade" (p. 42). Thus these researchers concede that the world system theory needs some refinement as suggested in this essay. The present study sees the three center-clustersNAFTA, EU, and Asia-Pacific - as the most evident structure of the contemporary world-economy. Starting from this totality, network analysis could trace relations within each cluster and among the three clusters and their hinterlands in relation to better-conceptualized research problems. Network analysis could provide new insights if it were to analyze the $\mathrm{EU}$ as a single economic unit rather than as I5 separate political units thereby reducing the current Eurocentric bias. Each of the three center-clusters can be analyzed similarly.

A crucial need is to answer the following questions: What is international communication; and should there be a distinction between mass communication and other forms of communication such as travel, tourism and migration? Multiple-network analysis encompassing a variety of communication variables would be the most beneficial though the most difficult to do. If the triadization concept were to be incongruent with the pattern of world communication, that may indicate the need to separate the world communication or language order from the world economic order.
The work of Barnett and colleagues in the communication field need further confirmation (for validity and reliability) using all pertinent research approaches. Chase-Dunn and Grimes (1995) say"some excellent work has attempted empirically to measure the placement of states in the core/periphery hierarchy" ( $\mathrm{p}$. 397) using a number of research tools. The essential requirement is to move the research focus away from the atom (i.e., the nation-state) to the whole (i.e., the world system). Thus the analysis of global communication should move in descending order from the world-economy to the center-clusters and their respective hinterlands, i.e., the periphery-clusters, and only then to the globalstates within each of the clusters. Researchers could redefine the center-clusters or the periphery-clusters to achieve the desired accuracy. For instance, they could expand the EU cluster (ISPI = 26.613) into a Western Europe cluster (ISPI = 28.025) by adding Western Europe's OECD states excluded from the European Union: Switzerland, Norway and Iceland.

The arrows in Figure $\mathrm{I}$ indicate the potential interrelationships between and among the various clusters. The bold double-arrow lines show the hypothetical higher information and communication flow between and among the three competing center-clusters. The thin double-arrow lines show the hypothetical higher information and communication flow between each center-cluster and its hinterland. The broken double-arrow lines show the hypothetical lower information and communication flow between hinterlands and external center-clusters. This model presumes a very low flow among the hinterlands themselves.

Within this framework, researchers can test hypotheses covering all five elements in Lasswell's (1948) transmission model: Who (Source) says what (Message) to whom (Receiver) through what medium (Channel) with what effect (Impact). Here are two examples of plausible hypotheses related to sourcemessage-receiver elements:

+ Information and communication flow within each center-cluster and its respective hinterland would be greater than the flow across competing center-hinterland configurations. ${ }^{10}$

10. The aforementioned reader also pointed out that Fuentes-Bautista (1999) had examined trade and telecommunication flows in the Americas and found that trade blocs did not have an impact on regional communication, although they did effect trade. The study showed one group centered on the United States. This too points out to the need for more research by different researchers. It also suggests a need to differentiate between communication and mass communication with more widely acceptable operational definitions. 
- Information and communication flow from the hegemon center-cluster to each of the other two center-clusters would be greater than the flow from the remaining center-cluster. The flow to the hegemon center-cluster from the other two center-clusters favors the one that has the higher ISPI score (i.e., EU cluster).

An example of a medium-related hypothesis would be:

+ Mass media density in each of the center-hinterland configurations, as well as in its component global-states, generally follows the pattern of its respective ISPI score.

The proposed model also provides a challenge to researchers who are engaged in mapping press freedom in the world (e.g., Van Belle 2000; Weaver, Buddenbaum \& Fair 1985). The structural-functionalist modernization paradigm, which presumed that nation-states changed in parallel lines from tradition to modernity, placed media participation, with accompanying press freedom, as another facet of development. Thus it placed press freedom outside the context of the world system. Freedom House, for instance, measures press freedom using four criteria solely internal to a state: laws and regulations, political pressures and controls, economic influences, and repressive action (Sussman 2000). My model requires linking the notion of press freedom to global forces, such as the ability of center-clusters to flood the periphery-clusters with a barrage of informationcommunication notwithstanding the domestic restrictions within a state. So conceived, the measurement of press freedom should include the accessibility of information from non-domestic sources. ${ }^{11}$ Moreover, if we were to presume the libertarian concept-"a free flow of information unimpeded by any intervention by any nation" (Hachten 1999:2I) — as the best expression of press freedom, then, research must also address the issue of global press freedom vis-à-vis the vast volume of government-sponsored global news flow (e.g*, Voice of America, Radio Moscow, Radio France Internationale, etc.).

As noted in the literature review, the world system perspective also provides a challenge to developmental-communication researchers to look into the global links that limit or facilitate a nation's competitive edge in capital accumulation.

11. The MacBride Report (1980) attempted to place press freedom in a global context. It affirmed everyone's right to freedom of expression, which includes freedom to hold opinions without interference and to seek, receive and impart information and ideas through any media and regardless of frontiers, as articulated in Article is the Universal Declaration of Human Rights. (Note that this right belongs to the individual, not the media institutions.) The report also drew attention to the 1952 Convention on the International Right of Correction (Recommendation 48).
The concept of developmental communication, as well as that of developmental journalism, which is predicated on the modernization paradigm, requires a thorough re-examination. Elevating the quality of journalism globally, and in the periphery-clusters in particular, may serve a much more useful purpose than a restricted brand of developmental journalism that hardly commands an audience.

Although the world system perspective is solidly based on economics, its strength depends on its ability to provide a testing ground of hypotheses associated with all other social sciences. Wallerstein (1979) maintains that history and the social sciences-anthropology, economics, geography, political science, and sociology - are just "one subject matter" that one may call "historical social science" ( $p+i x)$; and that the world-systems theory is a by-product of the application of historical social science. If economic criteria are implicitly integral to all social sciences, then the present study's theoretical approach should be eminently suitable for culture-and communication research as well. Frank and Gills (1993) assert that the world system theory accommodates scholarship in a variety of disciplines. Anthropologists (Kearney 1995) and geographers (Straussfogel 1997) are among the social scientists who have attempted to integrate it into their fields.

Relating the world-systems theory to international communication, anthropologist Kearney (1995) points out the three successive dominant paradigms in the field: the communication and development model, the cultural imperialism model, and the cultural pluralism model, "which is still exploring the dynamics of media in a world in which the distinction between centers and peripheries has largely dissolved with respect to media production and consumption" (p. 555). Global communication researchers stand to gain by adopting the world system theory to examine this issue and much more. Tomlinson (1997:174), for instance, sees advantages "in the recuperation of globalization within international or 'global sociology'... or in Immanuel Wallerstein's contributions to debates on global culture, framed firmly in the perspective of world-system theory," which may well accommodate the analysis of the postmodern condition of compression of time and space (Harvey 1989), as well as action at distance associated with theories of structuration and the nature of modernity (Giddens 1994). Tomlinson (I99I), however, has criticized Schiller (1979) for using the macro-political economy approach of the world-system theory to equate cultural domination or "media imperialism" with economic domination with no attempt to show empirical evidence relating to the cultural effects of such domination on the receivers.

As stated in the introduction, the particular contribution of the proposed theoretical approach is the potential it offers to examine global or international communication patterns/processes (source-message-medium-receiver-impact) 
holistically by recognizing the part-whole interrelationships of all theoretical components of the world system. The application of network analysis to macrounits (the triadized economic clusters), where reliable data are available, is likely to produce new insights on the interrelationships of those units. Moreover, the emphasis on part-whole interaction will improve our understanding of press freedom, development, and other communication-related phenomena that researchers have examined "atomistically" for the most part. Because no nation (atom) can exist outside of the world system (whole), research based solely on endogenous conditions will reflect only partial reality.

\section{REFERENCES}

Barnett, G.A. 200I. "A Longitudinal Analysis of the International Telecommunication Network, 1978-1996." American Behavioral Scientist, 44, I638-1655.

Barnett, G.A., \& Choi, Y. 1995. "Physical Distance and Language as Determinants of the International Communication Network." International Political Science Review, $16,249-265$.

Barnett, G.A., Jacobson, T., Choi, Y., \& Sun-Miller, S. 1996. "An Examination of the International Telecommunication Network." The Journal of International Communication, 3 (2), 19-43.

Barnett, G.A., Salisbury, J.G.T., Kim, C., \& Langhorne, A. 1999. "Globalization and International Communication: An Examination of Monetary,

Telecommunications, and Trade Networks. "The Journal of International Communication, 6 (2), 7-49.

Barnett, G.A., \& Salisbury, J.G.T. 1996. "Communication and Globalization: A Longitudinal Analysis of the International Telecommunication Network." Journal of World-Systems Research, 2 (I6), I-32. http://jwsr.ucr.edu/

Bergesen, A. 1990."Turning World-System Theory on its Head" Theory, Culture E Society, 7, 67-8I.

Bergesen, A.J., \& Sonnett, J. 200I."The Global 500: Mapping the World Economy at Century's End." American Behavioral Scientist, 44, 1602-1615.

Boorman, S., \& White, H. 1976. "Social Structure from Multiple Networks: Role Structures." American Journal of Sociology, 8, 1384-1446.

Boswell, T., \& Chase-Dunn, C. 2000. The Spiral of Capitalism and Socialism: Toward Global Dtemocracy. Boulder, CO: Lynne Rienner.

Braudel, F. 1967. Civilisation Materielle et Capitalisme. XV-XVII Siecle. Paris: Armand Colin.

Breiger, R. 1976. "Career Attributes and Network Structure: A Blockmodel Study of a Biomedical Research Specialty." American Sociological Review, 41, I17-135.

Castells, M. 1996. The Rise of the Network Society. The Information Age: Economy, Society and Culture Vol. 1. Cambridge, MA: Blackwell.

Chabot, C. 1996. Defining high technology [on-line]. http://www.stanford.edu/group/ $\underline{\text { STS/techno3.html }}$
Chang, T.K., Lau, T.U., \& Hao, X.M. 200o. "From the United States with News and More: International Flow, Television Coverage and the World System." Gazette, 62, $505-522$.

Chase-Dunn, C. 1999. “Globalization: A World-Systems Perspective.” Journal of WorldSystems Research, 5, 165-185. http://jwsr.ucr.edu/

Chase-Dunn, C., \& Grimes, P. 1995. "World-Systems Analysis." Annual Review of Sociology, 21, 387-417.

Choi, Y., \& Ahn, M. 1996. "Telecommunication, Transportation, and Trade Networks of 13 European Countries." Gazette, 58, 199-204.

Choi, Y., \& Ahn, M. 1994, July. Telecommunication, Transportation, and Trade in the Pacific Basin Community." Paper presented at the International Association of Mass Communication Research, Seoul.

DeVellis, R.F. 199I. Scale Development: Theory and Application. Newbury Park, CA: Sage.

Frank, A.G. 2000."Immanuel and Me With-Out Hyphen." Journal of World-Systems Research, 6, 216-231, http://jwsr.ucr.edu/

Frank, A.G. 1998. ReORIENT: Global Economy in the Asian Age." Berkeley: University of California Press.

Frank, A.G., \& Gills, B.K. (Eds.). 1993. The World System: Five Hundred Years or Five Thousand? London: Routledge.

Fuentes-Bautista, M. 1999. Communication and Regionalism: A Network Analysis of the Americas. Unpublished master's thesis, State University of New York at Buffalo, New York.

Galtung, J. 197I. "A Structural Theory of Imperialism." Journal of Peace Research, 8, $8 \mathrm{I}-\mathrm{II} 7$.

Galtung, J., \& Vincent, R.C. 1992. Global Glasnost: Toward a New World Information and Communication Order? Cresskill, NJ: Hampton Press.

Gereff, G. 200I. "Shifting Governance Structures in Global Commodity Chains, with Special Reference to the Internet." American Behavioral Scientist, 44, 1616-1637.

Giddens, A. 1994. Beyond Left and Right. Cambridge: Polity Press.

Glaeser, E. L. 1997. "Information Technology's Role.” In The Global Competitiveness Report 1997 (pp. 50-59). Geneva: World Economic Forum.

Goldfrank, W. L. 2000. "Paradigm Regained? The Rules of Wallerstein's World-System Method." Journal of World-Systems Research, 6, 150-195. http://jwsr.ucr.edu/

Gunaratne, S.A. 200Ia. "Prospects and Limitations of World System Theory for Media Analysis: The Case of the Middle East and North Africa." Gazette, 63 (2-3), I2I-I48.

Gunaratne, S.A. 200Ib. "Convergenceः Informatization, World System, and Developing Countries." In W.B. Gudykunst (Ed.), Communication Yearbook 25 (pp. 153-199). Mahwah, NJ: Lawrence Erlbaum.

Gunaratne, S.A. (Ed.). 2000. Handbook of the Media in Asia. New Delhi: Sage.

Gunaratne, S.A., \& Conteh, A. 1988. Global Communication and Dependency: Links Between the NIEO and NWICO Demands and the Withdrawals From UNESCO. Moorhead, MN: Moorhead State University. 
Hachten, W. A. 1999. The World News Prism: Changing Media of International Communication ( ${ }^{\text {th }}$ ed. $)$. Ames: Iowa State University Press.

Hargittai, E., \& Centeno, M.A. (Eds.). 200I. Mapping Globalization [Special Issue]. American Behavioral Scientist, 44 (I0).

Harvey, D. 1989. The Condition of Postmodernity: An Enquiry into the Origins of Cultural Change. Cambridge, MA: Blackwell.

Hier, S.P. 200I. "The Forgotten Architect: Cox, Wallerstein and World-System Theory. Race E Class, 42 (3), 69-86.

Hugill, P.J. 1999. Global Communications Since 1844: Geopolitics and Technology. Baltimore: The Johns Hopkins University Press.

Huntington, S.P. 1996. The Clash of Civilizations: Remaking of the World Order. New York: Touchstone.

International Monetary Fund. 1998. Direction of Trade Statistics Yearbook. Washington, DC: IMF,

International Telecommunication Union [ITU]. 1999. World Telecommunication Development Report. Geneva: ITU.

Internet Software Consortium [ISC]. 2000, July. Domain Survey. http://www.isc.org Kearney, M. 1995. "The Local and the Global: The Anthropology of Globalization and Transnationalism. "Annual Review of Anthropology, 24, 547-565.

Kick, E.L. 1987."World-System Structure, National Development, and the Prospects for a Socialist World Order." In T. Boswell and A. Bergesen (Eds.), America's Changing Role in the World System (pp. 127-155). New York: Praeger.

Kick, E.L., \& Davis, B.L. 200I."World-System Structure and Change: An Analysis of Global networks and Economic Growth Across Two Time Periods." American Behavioral Scientist, 44, 156I-1578.

Kim, K., \& Barnett, G.A. 1996. "The Determinants of International News Flow: A Network Analysis." Communication Research, 23, 323-252.

Knoke, D., \& Kuklinski, J. 1982. Network Analysis. Beverly Hills, CA: Sage.

Lasswell, H. D. 1948. "The Structure and Function of Communication in Society." In L. Bryson (Ed.), The Communication of Ideas. New York: Harper \& Bros.

Louch, H., Hargittai, E., \& Centeno, M.A. 1999."Phone Calls and Fax machines: The Limits to Globalization." The Washington Quarterly, 22 (2) 83-100.

MacBride Report. 1980. Many Voices, One World: Communication and Society Today and Tomorrow (Report of the International Commission for the Study of Communication Problems), Paris: UNESCO.

McMichael, P. 2000."World-Systems Analysis, Globalization, and Incorporated Comparison." Journal of World-Systems Research, 6, 668-690. http://jwsr.ucr.edu/

Mattelart, A. 2000. Networking the World 1794-2000 (L. Carey-Libbrecht \& J.A. Cohen, Trans.). Minneapolis: University of Minnesota Press. (Original work published 1996)

Mullins, N., Hargens, L., Hecht, P., \& Kick, E. 1977."The Group Structure of CoCitation Cultures: A Comparative Study.” American Sociological Review, 42, 214-235. National Science Board. 2000. Science E Engineering Indicators-2000. Washington, DC: U.S. Government Printing Office.
Netsizer. 2000, October. Internet Hosts and Users by Country. http //ww.netsizer.com Prigogine, I, \& Stengers, I. 1984. Order Out of Chaos: Man's Dialogue with Nature. New York: Bantam Books.

Sacks, M.A., Ventresca, M.J., \&Uzzi, B. 200I. "Global Institutions and Networks: Contingent Change in the Structure of World Trade Advantage, 1965-1980." American Behavioral Scientist, 44, 1579-160I.

Salisbury, J.G.T., \& Barnett, G.A. 1999. "A Network Analysis of International Monetary Flows." Information Society, 15, I-19.

Sanderson, S.K., \& Hall, T.D. 1995. "World-System Approaches to World-Historical Change." In S.K. Sanderson (Ed.), Civilizations and World Systems: Studying World-Historical Change pp. 95-108). Walnut Creek, CA: AltaMira Press.

Schiller, H.I. 1979."Transnational Media and National Development." In K. Nordenstreng and H.I. Schiller (Eds.), National Sovereignty and International Communication. Norwood, NJ: Ablex.

Schramm, W., \& Lerner, D. (Eds.). 1976. Communication and Change: The Last Ten Years-And the Next." Honolulu: The University Press of Hawaii.

Servaes, J. 1999. Communication for Development. Cresskill, NJ: Hampton Press.

Shah, H. 1996. "Modernization, Marginalization, and Emancipation: Toward a Normative Model of Journalism and National Development." Communication Theory, 6, 143-166.

Shannon, T. 1989. An Introduction to the World-System Perspective. Boulder, CO: Westview.

Sklair, L. 1999. "Competing Conceptions of Globalization." Journal of World-Systems Research, 5,143-162. http://jwsr.ucr.edu/

Smith, D.A., \& Timberlake, M.F. 200I."World City Networks and Hierarchies, 19771997: An Empirical Analysis of Global Sir-Travel Links.” American Behavioral Scientist, 44, I656-I678.

Smith, D.A., \& White, D.R. 1992. "Structure and Dynamic of the Global Economy: Network Analysis of International Trade 1965-1980." Social Forces, 70, 857-893.

Snyder, D., \& Kick, E.L. 1979."Structural Position in the World System and Economic Growth, 1955-1970: A Multiple Network Analysis of Transnational Interactions". American Journal of Sociology, 84, I096-II26.

Straussfogel, D. 1997. "A Systems Perspective on World-Systems Theory." Journal of Geography, 96, I19-126.

Sun, S., \& Barnett, G.A. 1994. "An Analysis of the International Telephone Network and Democratization." Journal of the American Society for Information Science, 45, $4 I I-42 I$.

Sussman, L. R. 2000. Censor Dot Gov: The Internet and Press Freedom. New York: Freedom House.

Tehranian, M. 1999. Global Communication and World Politics: Domination, Development, and Discourse. Boulder, CO: Lynne Rienner.

Teivainen, T. 2000."Towards a Democratic Theory of the World-System: Democracy, Territoriality, and Transnationalization." Journal of World-Systems Research, 6, 706-725. http://jwsr.ucr.edu/ 
Thussu, D.K. 2000. International Communication: Continuity and Change. London: Arnold.

Tomlinson, J. 1997. "Cultural Globalization and Cultural Imperialism." In A. Mohammadi (Ed.), International Communication and Globalization (pp. 170-190). London: Sage.

Tomlinson, J. 1991. Cultural Imperialism: A Critical Introduction. Baltimore: The Johns Hopkins University Press.

Townsend, A.M. 200I. "Network Cities and the Global Structure of the Internet." American Behavioral Scientist, 44, 1697-1716.

United Nations Development Program. 2000. Human Development Report. New York: Oxford University Press.

Van Belle, D.A. 2000. Press Freedom and Global Politics. Westport, CT: Praeger.

Van Rossem, R. 1996."The World System Paradigm as General Theory of Development: A Cross-National Test." American Sociological Review, 61, 508-527.

Volkmer, I. 1999. News in the Global Sphere: A Study of CNN and its Impact on Global Communication. Luton: University of Luton Press.

Wainer, H., \& Thissen, D. 1976. “Three Steps Towards Robust Regression. Psychometrika, 41, 9-34.

Wallerstein, I. 1979. The Capitalist World-Economy. Cambridge: Cambridge University Press.

Wallerstein, I. 1974. "The Rise and Future Demise of the World Capitalist System: Concepts for Comparative Analysis." Comparative Studies in Society and History, 16 (4), 387-4I5.

Weaver, D.H., Buddenbaum, J.M., \& Fair, J.E. 1985."Press Freedom, Media, and Development, 1950-1979: A Study of 134 Nations." Journal of Communication, 35 (2), IO4-II7.

World Bank. 1999, 2000. World Development Indicators. Washington, DC: International Bank for Reconstruction and Development.

World Trade Organization. 1999. Annual Report: International Trade Statistics. Geneva: WTO.

Wu, H. D. 2000."Systemic Determinants of International News Coverage: A Comparison of 38 Countries." Journal of Communication, 50 (2), 110-130.

Zook, M.A. 200I. "Old Hierarchies or New Networks of Centrality? The Global Geography of the Internet Content Market." American Behavioral Scientist, 44, I679-1696. 